\title{
MENGGUNAKAN MIKROALGA UNTUK MEREMEDIASI AIR TERCEMAR KLORPIRIFOS
}

\author{
Raudhatul Habibah \\ Jurusan Teknik Lingkungan, Fakultas Arsitektur Lanskap dan Teknologi Lingkungan, \\ Universitas Trisakti, Jakarta, Indonesia
}

Email korespondensi: raudatu108214054@std.trisakti.ac.id

\begin{abstract}
ABSTRAK
Karya ilmiah ini bertujuan untuk membahas mengenai remediasi air tercemar pestisida jenis klorpirifos dengan menggunakan mikroalga. Indonesia telah mengalami penurunan kualitas air akibat dari aktivitas manusia pada saat ini telah melebihi batas wajar terutama dalam pemakaian pestisida yang melebihi dari dosis takaran. Beberapa jenis pestisida memiliki daya racun yang tinggi, sehingga menyebabkan air tanah tercemar pestisida dan membahayakan lingkungan. Biasanya pestisida yang digunakan dalam sektor pertanian dan perkebunan yaitu jenis pestisida organik, dan termasuk dalam organofosfat yaitu klorpirifos. Oleh karena itu perlu dilakukan penanggulagan pada air tercemar klorpirifos dengan cara bioremediasi. Remediasi merupakan proses dekontaminasi air dan tanah dari senyawa yang berbahaya, seperti pestisida, logam berat dan lain-lain. Proses bioremediasi biasanya menggunakan mikroorganisme seperti bakteri, fungi, mikroalga atau enzimnya untuk dapat mengendalikan pencemaran dalam kondisi yang terkontrol menjadi suatu bahan yang tidak berbahaya atau konsentrasinya di bawah batas yang ditentukan dengan tujuan mengontrol atau mereduksi bahan pencemar dari lingkungan. Mikroorganisme yang digunakan untuk meremediasi klorpirifos yaitu mikroalga. Mikroalga adalah produsen utama dalam ekosistem perairan, karena mikroalga sangat sensitif terhadap berbagai jenis pencemaran lingkungan perairan. Teknologi bioremediasi lebih ramah lingkungan, dengan biaya relatif murah.
\end{abstract}

Kata Kunci: Klorpirifos, Bioremediasi, Mikroalga.

\section{PENDAHULUAN}

Menurut Hakiki, (2019) air yang digunakan untuk memenuhi kebutuhan sehari-hari manusia memiliki karakteristik yang berbeda ini di tergantung pada sifat dan jumlah zat yang terkandung, selalu mempengaruhi jenis perawatan yang diperlukan sebelum dapat dimanfaatkan dengan sesuai. Air merupakan bagian terpenting dalam irigasi yang tidak dapat dipisahkan dari bagian sektor pertanian dan perkebunan. Menurut Peraturan Menteri Kesehatan Nomor 32 tahun 2017, dengan standar dalam kualitas kesehatan lingkungan dan air, beberapa fisik, kimia dan parameter biologi dinyatakan yang meliputi standar yang harus diperoleh untuk air untuk digunakan secara aman oleh manusia.

Di Indonesia telah mengalami penurunan kualitas air karena berbagai aktivitas manusia seperti perumahan, pertanian dan industri. Penurunan kualitas air yang disebabkan oleh pertanian dan perkebunan karena untuk meningkatkan produksi perkebunan dan pertanian, baik kuantitatif dan kualitatif telah mendukung penggunaan pestisida.

Dalam implementasinya, penggunaan pestisida ini sering tidak mengikuti aturan, yang cenderung dalam jumlah tinggi untuk mendapatkan hasil cepat dalam menghentikan pertumbuhan hama dan penyakit, sebagian besar atau bahkan semua akan jatuh ke air dan mencemari perairan. Pestisida yang digunakan di ladang pertanian ini yaitu jenis pestisida organik golongan organofosfat yaitu klorpirifos.

Chlorpyrifos digunakan sebagai model yang baik untuk menyelidiki efek ekotoksikologisnya pada mikroalga air tawar. Untuk mengatasi polutan, mikroalga air tawar dianggap sebagai sampel yang baik untuk meneliti dampak pestisida seperti Chlorpyrifos pada spesies kehidupan air. 
Mikroalga sangat sensitif terhadap berbagai jenis pencemaran lingkungan perairan karena keuntungannya, banyak penelitian mengeksploitasi mikroalga air tawar sebagai organisme pengujian ekologis. Mikroalga air adalah produsen utama dalam ekosistem perairan dan dengan demikian, menjadi indeks penting untuk menilai kualitas air (Li, dkk., 2013; Wen, dkk., 2011).

Remediasi merupakan proses dekontaminasi air dan tanah dari senyawa yang berbahaya, seperti hidrokarbon, poliaromatik hidrokarbon $(\mathrm{PAH})$, persistant organic pollutant (POP), logam berat, pestisida dan lain-lain. Belakangan ini teknik remediasi lingkungan tersemar banyak menggunakan cara biologis (bio-remediasi), karena pertimbanagn efek samping yang dihasilkannya dan biaya operasional. Remediasi pada lingkungan oleh bakteri (Zahoor \& Rehman, 2009; (De, Ramaiah, \& Vardanyan, 2008) dan juga mikro alga (Rahman, Ellis, \& Miller, 2012).

Vidali, (2011), dan Singh, dkk., (2006) menjelaskan bahwa bioremediasi adalah proses penguraian limbah organik/anorganik polutan dari sampah organik dengan menggunakan organisme (bakteri, fungi, tanaman, mikroalga atau enzimnya) dalam mengendalikan pencemaran pada kondisi terkontrol menjadi suatu bahan yang tidak berbahaya atau konsentrasinya di bawah batas yang ditentukan oleh lembaga berwenang dengan tujuan mengontrol atau mereduksi bahan pencemar dari lingkungan. Kelebihan teknologi bioremedisi ditinjau dari aspek komersil adalah relatif lebih ramah lingkungan, biaya penanganan yang relatif lebih murah dan bersifat fleksibel (Angga, 2011).

Karya ilmiah ini bertujuan tujuan untuk mempelajari bioremediasi air tercemar akibat klorpirifos dengan menggunakan mikroalga.

\section{TINJAUAN PUSTAKA}

\section{KLORPIRIFOS dan DAMPAK KLORPIRIFOS BAGI LINGKUNGAN}

Solomon dkk, (2014) menjelaskan bahwa Chlorpyrifos (0,0-diethyl-3,5,6- trichloro2- pyridylphosphorothioate) adalah insektisida/acaricide untuk perawatan tanaman, rumput, tanaman hias. Klorpirifos umumnya digunakan untuk mengontrol dedaunan dan tanah serangga hama pada berbagai tanaman pangan dan pakan. Pada umumnya penggunaan klorpirifos meliputi pemeliharaan lanskap, pengendalian hama struktural, semprotan yang tidak aktif, dan produk hewan peliharaan. Ini salah satu insektisida organofosfor yang paling banyak digunakan di Indonesia kegiatan pertanian di Argentina (CASAFE, 2009). Klorpirifos adalah insektisida kelompok organofosfat yang bersifat non sistemik , bekerja saat terjadi kontak dengan kulit, termakan (masuk ke lambung), dan terhirup (masuk ke sistem pernafasan).

\section{ANALISIS PENYISIHAN KLORPIRIFOS}

Penyisihan klorpirifos akan dianalisis menggunakan metode Gas ChromatograohyMass Spectrometer (GC - MS). Pengolahan data kuantitatif dapat dilakukan setelah melakukan analisis dengan rumus sebagai berikut:

$$
\begin{array}{r}
\frac{A u}{x c b^{\frac{V b}{}} \times V e} \\
R=\frac{A b \quad V u}{}
\end{array}
$$

$W u$

R: klorpirifos tingkat (ppm), Au: daerah Kromatogram dari sampel, Ab: Standard daerah Kromatogram, Cb: Standard Konsentrasi (ng / ml), Vb: Volume disuntikkan larutan standar 
(ml), Vu: Volume sampel disuntikkan solusi (ml), Ve: Volume final ekstrak sampel (ml), $\mathrm{Wu}$ : contoh berat $(\mathrm{g})$.

Analisis presentase konsentrasi klorpirifos yang disishkan dapat dihitung dengan rumus sebagai berikut:

$\%$ Penyisihan $=[($ So - S $) /$ So $] \times 100 \%$

So: Konsentrasi awal klorpirifos (ppm), S: Konsentrasi akhir klorpirifos (ppm).

\section{BIOREMEDIASI}

Menurut Vidali, (2011), Bioremediasi adalah proses penguraian limbah organik/anorganik polutan dari sampah organik dengan menggunakan organisme (bakteri, fungi, tanaman atau enzimnya) dalam mengendalikan pencemaran pada kondisi terkontrol menjadi suatu bahan yang tidak berbahaya atau konsentrasinya di bawah batas yang ditentukan oleh lembaga berwenang dengan tujuan mengontrol atau mereduksi bahan pencemar dari lingkungan.

\section{MIKROALGA}

Mata dkk, (2010) menjelaskan bahwa mikroalga adalah mikroorganisme fotosintesis prokariotik atau eukariotik yang dapat tumbuh dengan cepat dan hidup dalam kondisi yang keras karena struktur multiseluler uniseluler atau sederhana. Menurut Brennan dan Owende (2010), Mikroalga dianggap sebagai tanaman primitif yaitu, tidak memiliki akar, batang dan daun, yang tidak memiliki penutup sel steril di sekitar sel reproduksi dan memiliki klorofil sebagai pigmen fotosintesis primer.

Menurut Zhu (2014), mikroalga akan mengalami kejenuhan akibat kekurangan nutrient dari medium pertumbuhannya sehingga jumlah sel yang mati akan makin meningkat, peristiwa tersebut akan mengakibatkan terjadinya fase kematian. Fase pertumbuhan mikroalga dapat ditunjukkan pada Gambar 1.

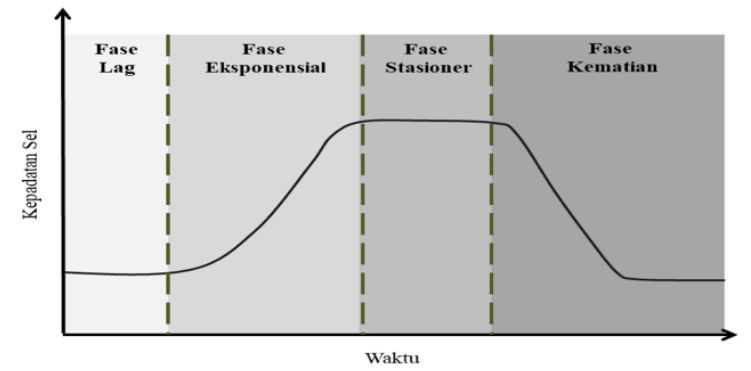

Gambar 2.1 Kurva Fase Pertumbuhan Mikroalga

(Sumber : Zhu, 2014)

Pertumbuhan mikroalga dipengaruhi oleh ketersediaan nutrisi, suhu, cahaya dan $\mathrm{pH}$. Berikut merupakan faktor yang mempengaruhi laju pertumbuhan mikroalga :

a. Intensitas Cahaya

Menurut Ye dkk., (2012), cahaya memiliki tingkat kejenuhan maka apabila cahaya telah melewati titik jenuh, tidak ada peningkatan pertumbuhan mikroalga walaupun intensitas cahaya meningkat dan akan mengalami photoinhibition.

b. Temperatur

Pertumbuhan mikroalga dipengaruhi oleh temperatur. Sebagian mikroalga dapat tumbuh pada temperatur $15^{\circ} \mathrm{C}$ sampai $40^{\circ} \mathrm{C}$. Apabila temperatur $>40^{\circ} \mathrm{C}$ maka mikroalga 
tersebut tidak akan tumbuh (Mata dkk., 2010). Suhu ideal untuk pertumbuhan mikroalga yaitu $20^{\circ} \mathrm{C}$ sampai $30^{\circ} \mathrm{C}$.

c. Nutrisi

Nutrisi yang dibutuhkan terdiri dari makronutrien (karbon, nitrogen, hidrogen, sulfur, kalium, magnesium dan posfor), mikronutrien (zat besi, boron, mangan, vanadium, silikon, selenium, tembaga, nikel dan molibdenum), dan vitamin. Ito, dkk. (2013) menjelaskan "bahwa kekurangan nitrogen dapat menyebabkan penurunan asam amino dalam sel dan unsur nitrogen dapat mempengaruhi laju pertumbuhan dan pembelahan".

d. Oksigen

Lannan, (2011) menjelaskan bahwa oksigen yang tidak terakumulasi dengan baik maka akan menyebabkan kerusakan fotooksidatif sehingga menghambat proses fotosintesis dan mengurangi produksi biomassa yang dihasilkan.

e. $\mathrm{pH}$

Menurut Feng dkk, (2011), nilai pH disesuaikan dengan media pertumbuhan mikroalga, nilai pH yang sesuai untuk mikroalga umumnya 6 - 8 (Feng, dkk., 2011). Kisaran pH optimum untuk mikroalga laut yaitu 7.8 - 8.5. Semakin tinggi kerapatan sel pada medium kultur akan menyebabkan meningkatnya kondisi media kultur ( $\mathrm{pH}$ semakin tinggi) dan menyebabkan peningkatan $\mathrm{CO}_{2}$ terlarut dalam medium.

\section{PENGARUH KLORPIRIFOS PADA PERTUMBUHAN MIKROALGA}

Dari penelitian sebelumnya Menurut Viviana dkk, (2015) semua konsentrasi klorpirifos diuji untuk menghambat pertumbuhan mikroalga $A$. gracilis. Pada awal bioassay yaitu, 24 dan 48 jam paparan, perawatan dengan 9,37, 18,75 dan 37,5 mg L-1 klorpirifos tidak secara signifikan menghambat pertumbuhan mikroalga $A$. gracilis, sedangkan konsentrasi yang lebih tinggi (75 dan $150 \mathrm{mg}$ L- 1) secara signifikan menghambat pertumbuhan alga dibandingkan dengan kultur kontrol (F $1 / 4$ 9,72; p 1/4 0,007 pada 24 jam dan F 1/4 48,92; p 1/4 0,0001 pada 48 h).

Waktu paparan meningkat (yaitu, 72 dan $96 \mathrm{~h}$ waktu-poin), pertumbuhan alga statistik signifikan lebih rendah daripada di kontrol diamati pada semua perlakuan kecuali pada 9,37 mg L-1 dari pyrifos chlor- (F 1/4 71,02; $\mathrm{p} 00.0001$ pada 72 jam dan F $1 / 4$ 37,84; p 1/4 0,0002 pada $96 \mathrm{~h}$ ). Kultur terkena $150 \mathrm{mg} \mathrm{L}-1$ klorpirifos tidak pertumbuhan penduduk ini, menjaga jumlah sel yang sama seperti yang diinokulasi pada awal bioassay tersebut.

Waktu generasi (Gt) disajikan pola respon yang mirip dengan laju pertumbuhan. EC50 saya di akhir bioassay itu dari 22,44 mg L-1 klorpirifos dengan interval kepercayaan diri $(95 \% \mathrm{CI})$ mulai 18,28-26,80 mg L-1.

\section{PENUTUP}

\section{KESIMPULAN}

Mikroalga berpotensi sebagai bioremedian untuk mendegradasi pestisida jenis klorpirifos

\section{DAFTAR PUSTAKA}

Angga, 2011, Konservasi Tanah dan Remediasi dalam http://angga. staff.ipb. ac.id /files/2011/04/10-Konservasi-Tanah-Remediasi.pdf.

Brennan L, Owende P. 2010. Biofuels from microalgae-A review of technologies for production processing, and extractions of biofuels and co-products. Renewable \& Sustainable Energy Reviews Journal 14:557-577 DOI 10.1016/j.rser.2009.10.009.

CASAFE (Cámara de sanidad agropecuaria y fertilizantes), 2009. Guía de productos fitosanitarios para la República Argentina. Buenos Aires, Argentina. http://dx.doi.org/10.1016/j.ecoenv.2015.06.015. 
De, J., Ramaiah, N., \& Vardanyan, L. (2008). Detoxification of Toxic Heavy Metals by MarineBacteria Highly Resistant to Mercury. Marine Biotechnology , 10 (4), 471-477.

Djojosumarto, P. 2008. Panduan Lengkap Pestisida dan Aplikasinya. Jakarta : Agromedia Pustaka.

Feng, Y., Li, C., \& Zhang, D. 2011. Lipid production of Chlorella vulgaris cultured in artificial wastewater medium. Bioresource Technology, 102(1), 101-105.

Hakiki, Wikaningrum. 2019. The Prospect Of Digitally Enhanced Colorimetry As An Analytical Method For Water Quality Determination. 2, (2), 146-163. DOI : http://dx.doi.org/10.25105/urbanenvirotech.v2i2.4362.

Ito, T., Tanaka, M., Shinkawa, H., Nakada, T., Ano, Y., Kurano, N., Tomita, M. 2013. Metabolic and morphological changes of an oil accumulating trebouxiophycean alga in nitrogen-deficient conditions. Metabolomics, 9(SUPPL.1), 178-187.

Kementerian Kesehatan. 2017. Peraturan Menteri Kesehatan Republik Indonesia Nomor 32 Tahun 2017 TENTANG Standar Baku Mutu Kesehatan Lingkungan Dan Persyaratan Kesehatan Air untuk review Keperluan Higiene Sanitasi, Kolam Renang, Solus per Aqua, Dan Pemandian Umum. DOI: http://dx.doi.org/10.25105/urbanenvirotech.v2i2.4362.

Lannan, E., \& Lannan, E. 2011. Scale-up of algae growth system to cleanse wastewater and produce oils for biodiesel production. Rochester Institute of Technology.

Li, J.Y., Dodgen, L., Ye, Q. F., Gan, J., 2013. Degradation kinetics and metabolites of carbamazepine in soil. Environ. Sci. Technol. 47, 3678-3684. http://dx.doi.org/10.1016/j.biortech.2016.01.038.

Mata TM, Martins AA, Caetano NS. Microalgae for biodiesel production and other applications: a review. Renew. Sustain. Energy Rev. 2010; 14:217-232. Bioresour Technol. 2016 May ; 207: 59-66. doi:10.1016/j.biortech.2016.01.103.

Rahman, A., Ellis, J. T., \& Miller, C. D. (2012). Bioremediation of Domestic Wastewater and Production of Bioproducts from Microalgae Using Waste Stabilization Ponds. Journal of Bioremediation and Biodegradation. , 3, 2155 - 6199.

Singh BK, Walker A. Microbial degradation of organophosphorus compounds. FEMS Microbiol Rev 2006;30:428-71. http://dx.doi.org/10.1016/j.envint.2012.10.007.

Solomon, K.R., Williams, W.M., Mackay, D., Purdy, J., Giddings, J.M., Giesy, J.P., 2014. Properties and uses of chlorpyrifos in the United States. In: Giesy. J.P., Solomon, K.R. (Eds.) Ecological risk assessment for chlorpyrifos in terrestrial and aquatic systems in the United States. Reviews of Environmental Contamination and Toxicology, 231, 13-34. http://dx.doi.org/10.1016/j.ecoenv.2015.06.015.

Vidali, M. 2011. Bioremediation. An overview. Pure Appl. Chem. 73: 1163-1172.

Viviana, A., Carolina, F., Yolanda, Z., Elisa, R.P., 2015. Effects of chlorpyrifos on the growth and ultrastructure of green algae, Ankistrodesmus gracilis, Ecotoxocology and Environmental Safety, 120, 334-34. http://dx.doi.org/10.1016/j.ecoenv.2015.06.015

Wen, Y.Z., Chen, H., Shen, C.S., Zhao, M.R., Liu, W.P., 2011. Enantioselectivity tuning of chiral herbicide dichlorprop by copper: roles of reactive oxygen species. Environ. Sci. Technol. 45, 4778-4784. http://dx.doi.org/doi:10.1016/j.etap.2016.05.032.

Ye, C. P., Zhang, M. C., Yang, Y. F., \& Thirumaran, G. 2012. Photosynthetic performance in aquatic and terrestrial colonies of Nostoc flagelliforme (Cyanophyceae) under aquatic and aerial conditions. Journal of Arid Environments, 85, 56-61. 
Zahoor, A., \& Rehman, A. (2009). Isolation of Cr(VI) reducing bacteria from industrial effluents and their potential use in bioremediation of chromium containingwastewater.Journal of Environmental Sciences , 21 (6), 814 - 820.

Zhu, Liandong. 2014. Sustainable Biodiesel Production from Microalgae Cultivated with Piggery Wastewater. University of Vaasa. 